\title{
Screening of some savannah plants for antiretroviral (ANTI-HIV) activity
}

\author{
MD Mukhtar*1, AA Audu², OA Adoum², SY Mudi², BS Aliyu ${ }^{1}$, Y Mustapha1, \\ NT Dabo ${ }^{1}, \mathrm{M} \mathrm{Bashir}^{1}$ and AI Salisu ${ }^{3}$
}

Address: ${ }^{1}$ Department of Biological Sciences, Bayero University, P.M.B. 3011, Kano, Nigeria, ${ }^{2}$ Department of Pure and Industrial Chemistry, Bayero University, P.M.B. 3011, Kano, Nigeria and ${ }^{3}$ Department of Human Anatomy, Faculty of Medicine, Bayero University, P.M.B. 3011, Kano, Nigeria

* Corresponding author

from Frontiers of Retrovirology: Complex retroviruses, retroelements and their hosts Montpellier, France. 2I-23 September 2009

Published: 24 September 2009

Retrovirology 2009, 6(Suppl 2):P25 doi:10.1186/1742-4690-6-S2-P25

This abstract is available from: http://www.retrovirology.com/content/6/S2/P25

(c) 2009 Mukhtar et al; licensee BioMed Central Ltd.

Available data showed that there is at present a need for an increasing research momentum towards the discovery of an anti-retroviral drug, which could be used in the treatment and control of the most deadly disease, such as Acquired Immunodeficiency Syndrome (AIDS). Currently, Zidovudine (AZT), tamivudine (3Tc) and dideoxyinosine (ddI) are the most commonly employed drugs but with a minimal level of success. None of these available orthodox drugs for the treatment of this epidemic around the globe has so far provided the needed property of a good drug. These drugs are very expensive and beyond the reach of the average HIV patient in addition to their being very toxic in nature. There is a strong belief in the scientific community, that the active agent, which could successfully combat the HIV/AIDS virus, might be contained in medicinal plants. It is view that such isolate(s) will be safe and cheap to the average AIDS patient. This research is aimed at investigating whether the extracts from some suspected ethnomedicinal savannah plants possess any antiretroviral activity. Such plants would include Ceratotheca sesamoides, Amaranthus viridis, Senna occidentalis, Cassia singuena, Solanum americanum, Momordica balsaminia, Jatropha curcas, Vernonia amygdalina, Leptademia hastate, and Cassia tora. The plants extracts would be administered to HIV infected laboratory cultured human lymphocytes with a view to elucidating their potency and efficacy as candidates worthy of repute for further toxicological research towards the treatment of the disease. 